\title{
IMPLEMENTASI MODEL PEMBELAJARAN KOOPERATIF TIPE JIGSA W DENGAN MENGGUNAKAN PENDEKATAN ACTIVE LEARNING PADA MATERI BANGUN DATAR
}

\author{
Sukiyanto \\ STIT Al-Fatah Siman Lamongan \\ sukiyanto@stitaf.ac.id
}

\begin{abstract}
ABSTRAK
Jenis penelitian ini adalah deskriptif, karena dalam penelitian ini dilakukan untuk mengetahui bagaimana hasil aktivitas guru dalam mengelola pembelajaran, aktivitas siswa selama pembelajaran, respon siswa terhadap pembelajaran dan hasil belajar siswa setelah mengikuti pembelajaran. Penelitian ini di lakukan di SMA Unggulan BPPT Al-Fattah Lamongan. Subjek penelitian adalah siswa dikelas X MIPA-III pada tahun pelajaran 2018/2019 yang berjumlah 24 siswa. Teknik pengumpulan data menggunakan tiga jenis instrumen, yaitu: 1) Lembar observasi; 2) Angket; dan 3) Tes hasil belajar. Analisis data yang akan diperoleh dalam penelitian ini ada dua, yaitu : 1) Data kuantitatif, berupa skor tes hasil belajar; dan 2) Data kualitatif, berupa hasil lembar observasi dan angket. Data yang diperoleh kemudian dikumpulkan dan dianalisis secara deskriptif. Hasil penelitian menunjukan bahwa: (1) Kemampuan guru dalam mengelola pembelajaran terlaksana dengan sangat baik dengan mencapai skor 3,19 (2) Siswa aktif ketika pembelajaran berlangsung. Hasil pengamatan aktivitas siswa diperoleh aktivitas siswa aktif mencapai 96\%, sedangkan aktivitas siswa tidak aktif mencapai 4\% (3) Respon siswa terhadap pembelajaran sangat positif. Dari hasil angket respon siswa diperoleh 87,55\% siswa menjawab senang dan tidak senang diperoleh $12,55 \%$, siswa menjawab baru 88,09\%, dan 11,9\% siswa menjawab tidak baru, siswa menjawab setuju 88,50\% dan tidak setuju 12,50\%. (4) Hasil belajar siswa dengan model pembelajaran kooperatif tipe jigsaw dapat dikatakan efektif. Hal ini dapat dilihat dari nilai hasil persentase ketuntasan belajar siswa secara individu 77\% siswa tuntas dan $23 \%$ siswa tidak tuntas. Sedangkan secara klasikal ketuntasan belajar siswa mencapai $76,81 \%$ karena terdapat 3 siswa yang mendapat nilai $<75$.
\end{abstract}

Kata kunci: model pembelajaran tipe jigsaw, active learning, bangun datar.

\begin{abstract}
This type of research is descriptive, because in this study was conducted to find out how the results of teacher activities in managing learning, student activities during learning, student responses to learning and student learning outcomes after learning. This research was conducted in
\end{abstract}


the Superior High School of BPPT Al-Fattah Lamongan. The research subjects were students in class X MIPA-III in the 2018/2019 school year which amounted to 24 students. Data collection techniques use three types of instruments, namely: 1) observation sheet; 2) Questionnaire; and 3) Test of learning outcomes. There are two data analyzes to be obtained in this study, namely: 1) Quantitative data, in the form of learning outcomes test scores; and 2) Qualitative data, in the form of results of observation sheets and questionnaires. The data obtained were then collected and analyzed descriptively. The results of the study show that: (1) The teacher's ability to manage learning is done very well by achieving a score of 3.19 (2) Students are active when learning takes place. The results of observations of student activities obtained active student activities reached $96 \%$, while the activities of inactive students reached 4\%. (3) Student responses to learning are very positive. From the results of student questionnaire responses obtained $87.55 \%$ of students answered happy and unhappy obtained $12.55 \%$, students answered only $88.09 \%$, and $11.9 \%$ of students answered no new, students answered agreed $88.50 \%$ and did not agree 12.50\%. (4) Student learning outcomes with the jigsaw type cooperative learning model can be said to be effective. This can be seen from the results of the percentage of student learning completeness individually. $77 \%$ of students complete and $23 \%$ of students do not complete. While classically students' mastery learning reaches $76.81 \%$ because there are 3 students who get a value of $<75$.

Keywords: jigsaw learning model type, active learning, two-dimentional figure

\section{PENDAHULUAN}

Matematika merupakan ilmu universal yang berperan penting dalam berbagai disiplin ilmu, dan mengembangkan daya pikir manusia (Masykur, 2007). Besarnya peranan tersebut, menjadikan matematika sebagai mata pelajaran wajib di sekolah, dan perlunya penguasaan konsep yang kuat sejak dini, serta dapat menumbuhkan kemampuan siswa dalam berpikir logis, analitis, sistematis, kritis, kreatif dan bekerja sama secara efektif (Hardini, 2012) dengan tujuan agar siswa dapat memiliki kemampuan memperoleh, mengelola, memanfaatkan informasi dan kompetitif (Rusiyanti, 2011). Namun, sebagian besar siswa masih saja menganggap matematika sebagai mata pelajaran yang tidak menyenangkan, serta materinya yang terkesan sulit dan abstrak untuk dipahami (Yanto, 2018). Hal inilah yang berpotensi menjadi penyebab utama kesulitan belajar mereka.

Proses pembelajaran yang terjadi selama ini banyak guru yang menggunakan pembelajaran kovensional, yaitu model pembelajaran yang mengutamakan guru sebagai sumber informasi sedangkan siswa hanya sebagai 
penerima informasi yang mengakibatkan aktivitas berpusat pada guru (In'am, 2012). Khususnya pembelajaran matematika cenderung monoton dan tidak menarik, karena proses belajar mengajar yang lebih aktif adalah guru, sedangkan siswa pada umumnya cenderung pasif hanya menerima informasi yang diberikan oleh guru, siswa lebih banyak mendengar, menulis apa yang di informasikan oleh guru dan mengerjakan soal latihan. Sehingga dampak yang diperoleh pencapaian hasil ujian matematika di Indonesia termasuk kategori rendah, hal ini dapat dilihat dari perolehan hasil ujian yang dilaksanakan secara Nasional yang disebut dengan Nilai Ebtanas Murni (NEM).

Bangun datar adalah bangun dua dimensi yang tidak memiliki ruang tetapi hanya sebuah bidang. Metode pembelajaran matematika untuk materi bangun datar, pada umumnya guru hanya memberi informasi, menggambarkan contohcontoh bentuk bangun di papan tulis, siswa mencontoh gambar yang dicontohkan oleh guru untuk digambar di buku siswa. Berdasarkan hasil observasi awal diperoleh bahwa prestasi belajar matematika dalam hal ini kemampuan pemahaman konsep siswa rendah. Hal itu dapat dilihat dari nilai rata-rata kelas pada ulangan harian matematika siswa yang diperoleh hanya mencapai 73,50 tentang materi bangun datar. Sedangkan Kriteria Ketuntasan Minimal mata pelajaran matematika yang dibuat oleh guru adalah 75 . Penyebab rendahnya nilai matematika materi bangun datar tersebut, salah satu faktornya yaitu metode pembelajaran kurang tepat, minimnya media dalam pembelajaran dikelas, motivasi belajar siswa rendah, kurangnya perhatian siswa saat pelajaran berlangsung. Selain itu, guru masih mendominasi pelaksanaan pembelajaran matematika, dimana guru masih berperan sebagai sumber utama sekaligus faktor dalam pembelajaran. Sementara siswa hanya pasif mendengarkan kurang mandiri, sehingga siswa hanya menjadi robot penerima informasi tanpa dapat mengeksplorasi lebih dalam informasi yang sebenarnya sudah diperoleh siswa dari lingkungan sekitarnya.

Salah satu upaya untuk merubah kondisi tersebut adalah melalui model pembelajaran kooperatif tipe jigsaw dengan menggunakan pendekatan active learning. Hal ini sesuai dengan hasil penelitian Safrina, dkk (2014) bahwa model 
pembelajaran kooperatif merupakan pembelajaran dimana siswa dari level kemampuan yang berbeda bekerja bersama dalam kelompok-kelompok kecil untuk mencapai tujuan pembelajaran. Sedangkan Menurut Lie (2002), pembelajaran kooperatif dapat mencapai hasil yang maksimal apabila menerapkan lima unsur pembelajaran kooperatif, yaitu saling ketergantungan positif, tanggung jawab perseorangan, tatap muka, komunikasi antar anggota dan evaluasi proses kelompok.

Pembelajaran kooperatif merupakan model pembelajaran dengan pendekatan kontruktivis (Nur \& Wikandari, 1999). Dimana dalam pembelajaran ini menekankan aspek sosial. Melalui belajar secara berkelompok siswa dapat berinteraksi dan belajar menghormati pendapat siswa lain. Mereka dapat berbagi ilmu pengetahuan dan pengalaman dalam menyelesaikan permasalahanpermasalahan yang ia hadapi. Ada beberapa tipe pembelajaran kooperatif yaitu: 1). Student Teams Achievement Division (STAD); 2) Team Game Turnament (TGT); 3) Team Assisted Individualization (TAI); 4) Cooperative Integrated Reading and Composition (CIRC); 5) Group Investigation; 6) Jigsaw; dan 7) Learning Together (Slavin, 2015).

Salah satu model pembelajaran kooperatif yaitu tipe jigsaw dikembangkan oleh Aronson, dkk (Lie, 2002). Dalam teknik ini guru harus memperhatikan pengetahuan juga pengalaman siswa dan membantu siswa mengaktifkan pengetahuan dan pengalaman itu agar bahan bahan pelajaran menjadi lebih bermakna. Siswa juga harus bekerja sama dengan siswa lain dalam suasana berdiskusi dan mempunyai banyak kesempatan untuk mengolah informasi dan meningkatkan ketrampilan berkomunikasi (Lie, 2002).

Pembelajaran kooperatif tipe jigsaw merupakan salah satu tipe pembelajaran kooperatif yang mendorong siswa aktif dan saling membantu dalam menguasai materi pelajaran untuk mencapai prestasi yang maksimal. Dengan aktivitas yang dilakukan siswa, pembelajaran kooperatif menjadi relevan pula untuk digunakan dalam meningkatkan kerjasama siswa dalam kelompok (Lie, 2002). Dalam model belajar ini terdapat tahap-tahap dalam penyelenggaraannya. Tahap pertama siswa dikkelompokan dalam bentuk kelompok-kelompok kecil. Pembentukan kelompok-kelompok siswa tersebut dapat dilakukan guru 
berdasarkan pertimbangan tertentu (Isjoni, 2007), yaitu berdasarkan perbedaan kemampuan akademik, keaktifan siswa dan gender.

Langkah-langkah dalam model pembelajaran kooperatif tipe Jigsaw adalah sebagai berikut: a) Siswa dikelompokkan ke dalam 4 anggota tim; b) Tiap orang dalam tim diberi bagian materi yang berbeda; c) Tiap orang dalam tim diberi bagian materi yang ditugaskan; d) Anggota dari tim yang berbeda yang telah mempelajari bagian subbab yang sama bertemu dalam kelompok baru (kelompok ahli) untuk mendiskusikan subbab mereka; e) Setelah selesai diskusi sebagai tim ahli tiap anggota kembali ke kelompok asal dan bergantian mengajar teman satu tim mereka tentang sub bab yang mereka kuasai dan tiap anggota lainnya mendengarkan dengan sungguh-sungguh (Slavin, 2015).

Pembelajaran active learning merupakan proses pembelajaran yang tidak hanya didasarkan pada proses mendengarkan dan mencatat. Menurut Bonwell dan Eison (1991) berpendapat bahwa pembelajaran active learning adalah aktivitas intruksional yang melibatkan siswa dalam melakukan sesuatu dan berpikir tentang apa yang mereka lakukan. Sedangkan menurut Simons (1997) pembelajaran active learning memiliki dua jenis, yaitu pembelajaran mandiri (independent learning) dan bekerja secara aktif (active working). Independent learning merujuk pada keterlibatan siswa pada pembuatan keputusan tentang proses pembelajaran yang akan dilakukan. Active working merujuk pada situasi dimana pembelajar atau siswa ditantang untuk menggunakan kemampuan mentalnya saat melakukan pembelajaran. Dengan kata lain, bahwa pembelajaran pada dasarnya adalah pencarian secara aktif pengetahuan dan setiap orang belajar dengan cara yang berbeda.

Berdasarkan uraian tersebut, dapat dikatakan bahwa pembelajaran active learning pada prinsipnya merupakan model pembelajaran yang sangat menekankan aktifitas dan partisipasi peserta didik dalam proses pembelajaran. Oleh karena itu, peran pendidik dalam model pembelajaran ini tidak dominan menguasai proses pembelajaran, melainkan lebih berperan untuk memberikan kemudahan (fasilitator) dengan merangsang peserta didik untuk selalu aktif dalam segi fisik, mental, emosional, sosial, dan sebagainya. 
Tujuan dari pembelajaran matematika Sekolah Menengah Atas adalah untuk membantu siswa mempersiapkan diri agar sanggup menghadapi perubahan di dalam kehidupan dan didunia yang selalu berkembang, melalui latihan keterampilan bertindak atas dasar pemikiran secara logis, rasional dan kritis, serta mempersiapkan siswa agar dapat mempergunakan matematika dan pola pikir matematika dalam kehidupan sehari-hari dan dapat mempelajari berbagai ilmu pengetahuan pada bidang nya masing-masing (Sriyanto, 2007).

Melihat tujuan pembelajaran matematika di Sekolah Menengah Atas dan betapa pentingnya model pembelajaran kooperatif tipe jigsaw dan pendekatan active learning maka peneliti melakukan penelitian dengan judul "Implementasi model pembelajaran kooperatif tipe jigsaw dengan menggunakan pendekatan active learning pada materi bangun datar".

\section{METODE PENELITIAN}

Penelitian ini adalah menggunakan penelitian deskriptif, dimana penelitian ini akan memberikan gambaran tentang aktivitas guru dan siswa selama kegiatan belajar mengajar, gambaran tentang respon siswa dan hasil belajar siswa setelah mengikuti pelaksanaan model pembelajaran kooperatif tipe jigsaw dengan menggunakan pendekatan active learning pada materi bangun datar.

Penelitian ini di SMA Unggulan BPPT Al-Fattah Lamongan. Peneliti memilih subjek siswa yang duduk dikelas X MIPA-III pada tahun pelajaran 2018/2019 yang berjumlah 24 siswa. Teknik pengumpulan data menggunakan tiga jenis instrumen, yaitu: 1) Lembar observasi; 2) Angket; dan 3) Tes hasil belajar. Data yang diperoleh selanjutnya dianalisis secara deskriptif.

Analisis data yang akan diperoleh dalam penelitian ini ada dua, yaitu: 1) Data kuantitatif, berupa skor tes hasil belajar; dan 2) Data kualitatif, berupa hasil lembar observasi dan angket. Data yang diperoleh kemudian dikumpulkan dan dianalisis secara deskriptif.

1) Lembar Observasi

Data yang diperoleh dalam penelitian ini ada 2 macam, yang pertama data kuantitatif berupa skor tes, dan data kualitatif berupa hasil observasi dan angket 
yang diperoleh kemudian dikumpulkan dan dianalisis secara deskriptif. Data tersebut meliputi:

a. Data kemampuan guru dalam mengelola pembelajaran kooperatif jigsaw dengan pendekatan active learning, selama 2 kali pertemuan dengan kriteria penilaian sebagai berikut : 1 = kurang baik; 2 = cukup baik; 3 = baik; dan $4=$ sangat baik. Kemudian dicari rata-rata nilai untuk lima aspek yang diamati yaitu: 1) Pendahuluan; 2) Kegiatan inti; dan 3) Penutup.

Rata-rata nilai tersebut dikoneksikan dengan kriteria pada tabel sebagai berikut:

Tabel 1. Kriteria Penilaian Guru dalam Mengelola Model Pembelajaran Kooperatif Tipe Jigsaw

\begin{tabular}{clll}
\hline No & \multicolumn{1}{c}{ Kriteria } & & Kategori \\
\hline 1. & $3 \leq \mathrm{KGM}<4$ & Sangat baik & \\
2. & $2 \leq \mathrm{KGM}<3$ & Baik & \\
3. & $1 \leq \mathrm{KGM}<2$ & Cukup & \\
4. & $0 \leq \mathrm{KGM}<1$ & Jelek/Kurang & \\
\hline
\end{tabular}

Keterangan:

Sumber: (Kustianingsih, 2004)

$\mathrm{KGM}=$ Kemampuan guru mengelola pembelajaran

b. Data aktivitas siswa selama mengikuti proses pembelajaran dengan kooperatif jigsaw dengan pendekatan active learning pada materi bangun datar

$$
\text { Persentase }=\frac{\text { Jumlah frekwensi tiap aktivitas yang muncul }}{\text { Jumlah aktivitas keseluruhan }} \times 100 \%
$$

(Sugiyono, 2014)

Klasifikasi aktivitas siswa dibagi dalam dua bagian yaitu:

1. Aktivitas aktif, meliputi: membaca buku siswa/lembar ahli, berdiskusi antar siswa, berdiskusi/bertanya antara siswa dengan guru, menulis yang relevan dengan KBM, menjawab pertanyaan, mempresentasikan jawaban, mendengarkan/memperhatikan penjelasan guru.

2. Aktivitas tidak aktif, meliputi: aktivitas yang tidak relevan dengan KBM (seperti mengantuk, mengganggu teman, melamun dan keluar tanpa izin).

Selanjutnya dari pertemuan ke satu dan ke dua diambil rata-rata. Aktivitas siswa dapat dikategorikan aktif jika jumlah rata-rata persentase aktivitas aktif lebih besar dari jumlah rata-rata persentase aktivitas tidak aktif.

2) Angket 
Angket didapat dari siswa yang berisikan terkait dengan tanggapan siswa terkait dengan model pembelajaran kooperatif tipe jigsaw dengan menggunakan pendekatan active learning. Sedangkan cara menganalisis angket menggunakan rumus persentase sebagai berikut (Lince, 2001):

$$
\text { Pesersentase Jawaban Responden }=\frac{\sum \text { Jawaban Responden }}{\sum \text { Responden }} \times 100 \%
$$

Respon siswa dikatakan baik apabila rata-rata persentase jawaban dari tanggapan siswa yang senang/baru/setuju minimal mendapatkan nilai 80 atau memperoleh nilai $\geq 80 \%$.

\section{3) Tes Hasil Belajar}

Data tes yang dianalisis adalah hasil tes akhir, yaitu hasil belajar siswa setelah mengikuti model pembelajaran kooperatif tipe jigsaw dengan menggunakan pendekatan active learning. Sesuai dengan Kriteria Ketuntasan Minimum Siswa untuk mata pelajaran matematika di SMA Unggulan BPPT AlFattah Lamongan, seorang siswa dapat dikatakan tuntas dalam belajar apabila memperoleh nilai minimal 75 atau memperoleh nilai $\geq 75 \%$, dengan menggunakan perhitungan rumus persentase sebagai berikut (Sugiyono, 2014):

$$
\text { Nilai }=\frac{\text { Skor pemerolehan siswa }}{\text { Skor maksimum ideal }} \times 100 \%
$$

Adapun Instrumen dalam penelitian ini diberikan pada Tabel 2.

Tabel 2. Aktivitas Guru dalam Mengelola Model Pembelajaran kooperatif tipe jigsaw

\begin{tabular}{ccl}
\hline No & Kegiatan & \multicolumn{1}{c}{ Aspek yang diamati } \\
\hline 1. & Pendahuluan & Apersepsi \\
& & Menyampaikan tujuan pembelajaran \\
& Menjelaskan langkah-langkah pembelajaran kooperatif dengan tipe \\
& jigsaw. \\
& Menguasai media dalam pembelajaran \\
& Memotivasi siswa \\
& Mengkaitkan pembelajaran dengan pengetahuan yang dimilikinya \\
\hline 2. & Kegiatan inti & Menjelaskan materi yang akan dipelajari \\
& & Membimbing siswa dalam belajar kelompok \\
& & Mengamati setiap kelompok secara bergiliran \\
& & Membimbing siswa saat melakukan pembelajaran tipe jigsaw \\
& Penguasaan kelas \\
\hline 3. & Penutup & Memberi kesempatan kepada siswa yang belum paham untuk \\
& Bertanya \\
& Membimbing siwa membuat kesimpulan \\
& Kemampuan melakukan evaluasi \\
\hline
\end{tabular}

Modifikasi dari Thomas (2014). 


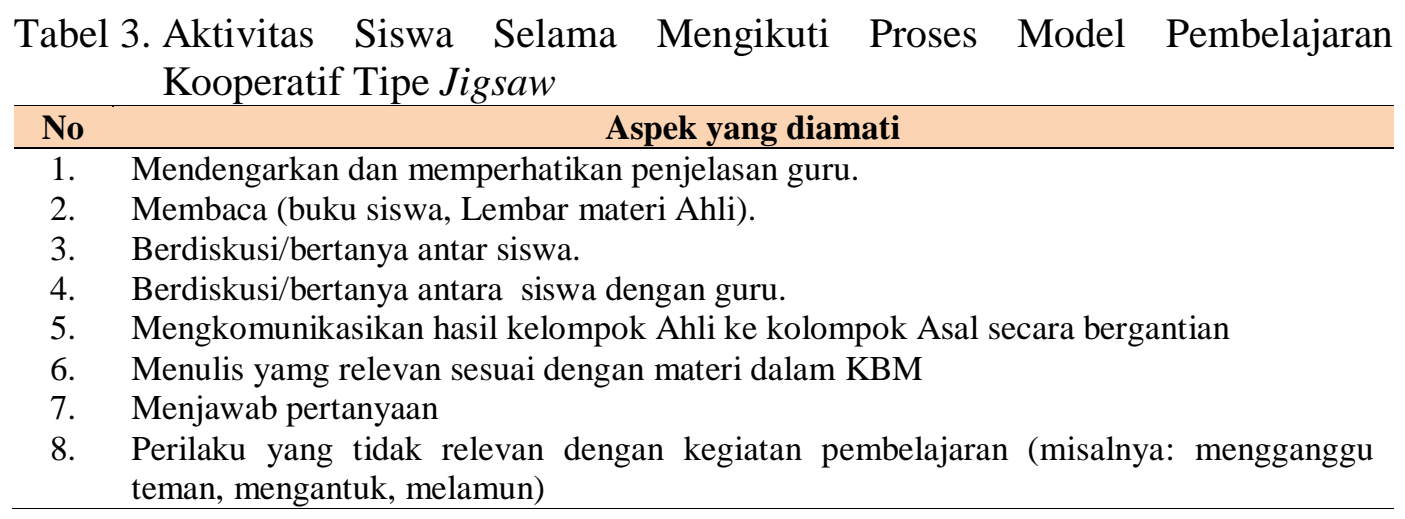

Tabel 4. Angket Respon Siswa Terhadap Model Pembelajaran Kooperatif Tipe Jigsaw

\begin{tabular}{cl}
\hline No & \multicolumn{1}{c}{ Pernyataan } \\
\hline 1. & Bagaimana tanggapan saudara selama mengikuti pembelajaran \\
2. & Bagaimana tanggapan saudara terhadap materi pelajaran \\
3. & Bagaimana tanggapan saudara terhadap buku lembar kerja siswa \\
4. & Bagaimana tanggapan saudara terhadap lembar materi ahli \\
5. & Bagaimana tanggapan saudara terhadap soal post test \\
6. & Bagaimana tanggapan saudara terhadap suasana belajar dikelas \\
7. & Bagaimana tanggapan saudara terhadap cara belajar \\
8. & Bagaimana tanggapan saudara terhadap cara guru mengajar \\
9. & Bagaimana pendapat saudara tentang materi pelajaran \\
10. Bagaimana pendapat saudara terhadap buku siswanya \\
11. Bagaimana pendapat saudara tentang lembar materi ahli \\
12. Bagaimana pendapat saudara tentang soal post test \\
13. Bagaimana pendapat saudara suasana belajar dikelas \\
14. Bagaimana pendapat saudara cara guru mengajar \\
15. Bagaimana pendapat saudara tentang model pembelajaran kooperatif dengan tipe jigsaw \\
16. Bang telah kalian ikuti \\
17. Bagaimana pendapat saudara jika pokok bahasan selanjutnya menggunakan model \\
\end{tabular}

Tabel 5. Soal Tes Kognitif Hasil Belajar Siswa

\begin{tabular}{|c|c|}
\hline No & Instrumen Soal \\
\hline 1. & $\begin{array}{l}\text { Sebuah taman berbentuk persegi panjang berukuran panjang } 32 \mathrm{~m} \text { dan lebar } 24 \mathrm{~m} \text {. } \\
\text { Disekeliling taman akan di pasang lampu dengan jarak antar lampu } 4 \mathrm{~m} \text {. Jumlah lampu } \\
\text { yang diperlukan adalah sebanyak? }\end{array}$ \\
\hline 2. & $\begin{array}{l}\text { Sebuah kebun berbentuk persegi panjang dengan ukuran } 34 \mathrm{~m} \times 16 \mathrm{~m} \text {. Disekeliling } \\
\text { kebun akan ditanami pohon mangga dan jarak antar pohon } 2 \mathrm{~m} \text {. Berapakah banyak } \\
\text { jumlah pohon mangga yang dapat ditanam? }\end{array}$ \\
\hline 3. & $\begin{array}{l}\text { April akan membuat kotak berbentuk balok dengan perbandingan panjang: lebar : tinggi } \\
=3: 2: 4 \text {. Jika panjang kotak tersebut } 15 \mathrm{~cm} \text {, berapakah luas seluruh permukaan } \\
\text { kotak? }\end{array}$ \\
\hline 4. & $\begin{array}{l}\text { Sebuah aula berbentuk balok dengan ukuran panjang } 10 \text { meter, lebar } 6 \text { meter, dan } \\
\text { tinggi } 5 \text { meter. Dinding bagian dalamnya di cat dengan biaya } R p 40.000,00 \text { per meter } \\
\text { persegi. Berapakah biaya pengecatan aula seluruhnya? }\end{array}$ \\
\hline 5. & $\begin{array}{l}\text { Sebuah kolam renang berbentuk persegi panjang berukuran panjang } 15 \mathrm{~m} \text { dan lebar } \\
10 \mathrm{~m} \text {. disekeliling kolam dibuat jalan dengan lebar } 1 \mathrm{~m} \text { dan dipasang keramik. }\end{array}$ \\
\hline
\end{tabular}


Berapakah luas keramik yang diperlukan untuk jalan?

\section{HASIL PENELITIAN DAN PEMBAHASAN}

Hasil dan pembahasan dalam penelitian ini dibagi menjadi dua, yaitu: 1) Aktivitas guru dalam mengelolah model pembelajaran kooperatif tipe jigsaw; 2) Aktivitas siswa dalam model pembelajaran kooperatif tipe jigsaw; 3) Respon siswa; 4) Hasil belajar aspek kognitif; 5) Ketuntasan pembelajaran pada butir soal. 1. Aktivitas guru dalam mengelolah model pembelajaran kooperatif tipe jigsaw

Nilai kemampuan guru dalam pengelolaan pembelajaran kooperatif tipe jigsaw dengan pendekatan active learning menggunakan analisis deskriptif yang sesuai dengan teknik analisa data yang telah dijelaskan diatas. Sesuai dengan hasil pengamatan, maka hasil aktivitas guru dalam mengelola pembelajaran kooperatif tipe jigsaw dapat dilihat pada tabel berikut:

Tabel 6. Aktivitas Guru dalam Mengelola Model Pembelajaran Kooperatif Tipe Jigsaw

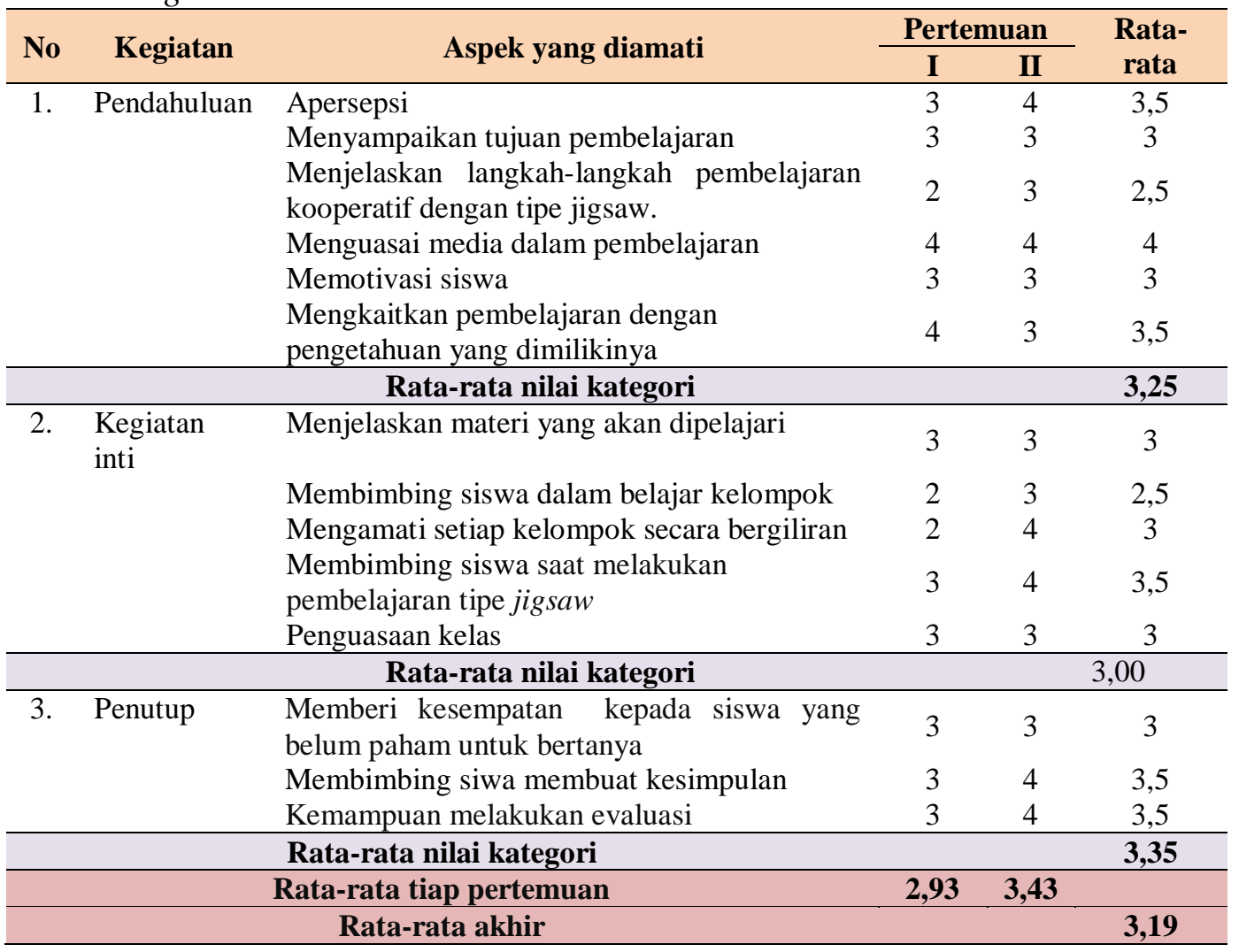

Dari Tabel 6 dapat digambarkan pada diagram batang Gambar 1. 


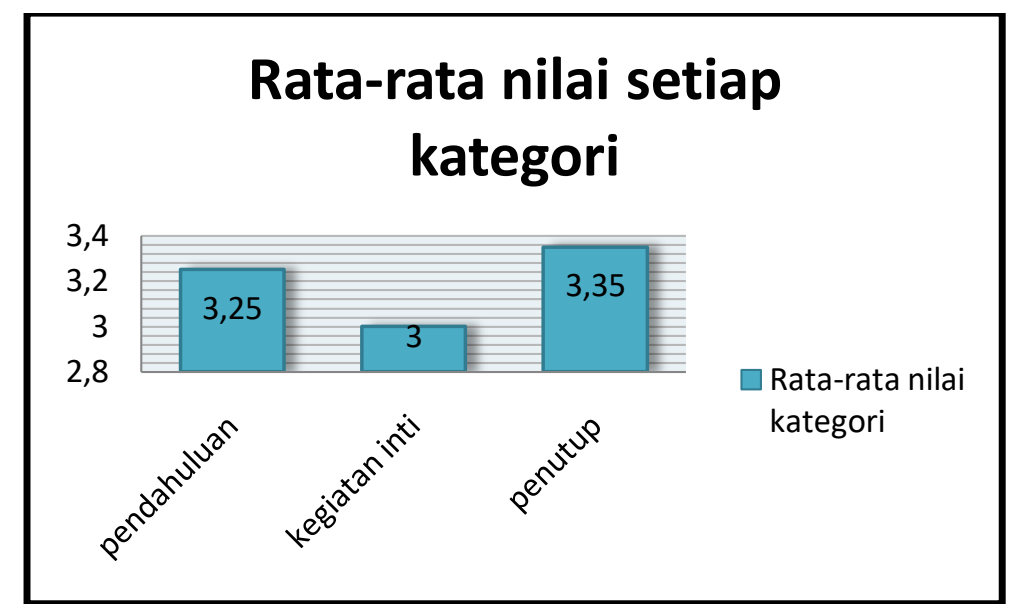

Gambar 1. Aktivitas Guru dalam Mengelola Model Pembelajaran Kooperatif Tipe Jigsaw

Berdasarkan Tabel 6 dan Gambar 1, menunjukkan bahwa kemampuan guru dalam mengelola model pembelajaran kooperatif tipe jigsaw dengan menggunakan pendekatan active learning untuk kriteria persiapan nila rataratanya adalah 3,00 yang berarti nilai kategori baik, sedangkan kriteria pelaksanaan yang meliputi pendahuluan mencapai nilai rata-ratanya adalah 3,25 yang menunjukkan kemampuan guru kategori sangat baik, Kriteria kegiatan inti mencapai nilai rata-ratanya adalah 3,00 yang menunjukkan kemampuan guru sudah baik, dan kegiatan guru dalam menutup pembelajaran nilai rata-ratanya adalah 3,25 yang berarti kemampuan guru sangat baik. Hasil tersebut dapat disimpulkan bahwa guru dalam mengelola model pembelajaran kooperatif tipe jigsaw dengan menggunakan pendekatan active learning adalah dapat dikategorikan sangat baik karena nilai rata-rata akhir dari seluruh kategori adalah 3,19 .

2. Aktivitas siswa dalam pembelajaran kooperatif tipe jigsaw.

Aktivitas siswa selama kegiatan pembelajaran kooperatif jigsaw dengan pendekatan active learning selama dua kali pertemuan. Data aktivitas siswa dapat dilihat pada Tabel 7.

Tabel 7. Aktivitas Siswa dalam Model Pembelajaran Kooperatif Tipe Jigsaw

\begin{tabular}{|c|c|c|c|c|}
\hline \multirow{2}{*}{ No } & \multirow{2}{*}{ Aspek yang diamati } & \multicolumn{2}{|c|}{ Pertemuan } & \multirow{2}{*}{$\begin{array}{l}\text { Rata- } \\
\text { Rata }\end{array}$} \\
\hline & & I & II & \\
\hline 1. & Mendengarkan dan memperhatikan penjelasan guru. & 10,4 & 6,77 & 8,59 \\
\hline 2. & Membaca (buku siswa, Lembar materi Ahli). & 13,5 & 15,6 & 14,55 \\
\hline 3. & Berdiskusi/bertanya antar siswa. & 10,9 & 11,5 & 11,20 \\
\hline 4. & Berdiskusi/bertanya antara siswa dengan guru. & 16,1 & 14.24 & 15,85 \\
\hline
\end{tabular}




\begin{tabular}{|c|c|c|c|c|}
\hline \multirow{2}{*}{ No } & \multirow{2}{*}{ Aspek yang diamati } & \multicolumn{2}{|c|}{ Pertemuan } & \multirow{2}{*}{$\begin{array}{l}\text { Rata- } \\
\text { Rata }\end{array}$} \\
\hline & & I & II & \\
\hline 5. & $\begin{array}{l}\text { Mengkomunikasikan hasil kelompok Ahli ke kolompok } \\
\text { Asal secara bergantian }\end{array}$ & 19,3 & 21,9 & 20,60 \\
\hline 6. & Menulis yang relevan sesuai dengan materi dalam KBM & 14,1 & 16,1 & 15,10 \\
\hline 7. & Menjawab pertanyaan & 10,4 & 8,85 & 9,63 \\
\hline 8. & $\begin{array}{l}\text { Perilaku yang tidak relevan dengan kegiatan pembelajaran } \\
\text { (misalnya : mengganggu teman, mengantuk,melamun) }\end{array}$ & 5,21 & 3,65 & 4,43 \\
\hline & Jumlah rata-rata & 100 & 100 & 100 \\
\hline
\end{tabular}

Dari Tabel 7 dapat digambarkan pada diagram lingkaran Gambar 2.

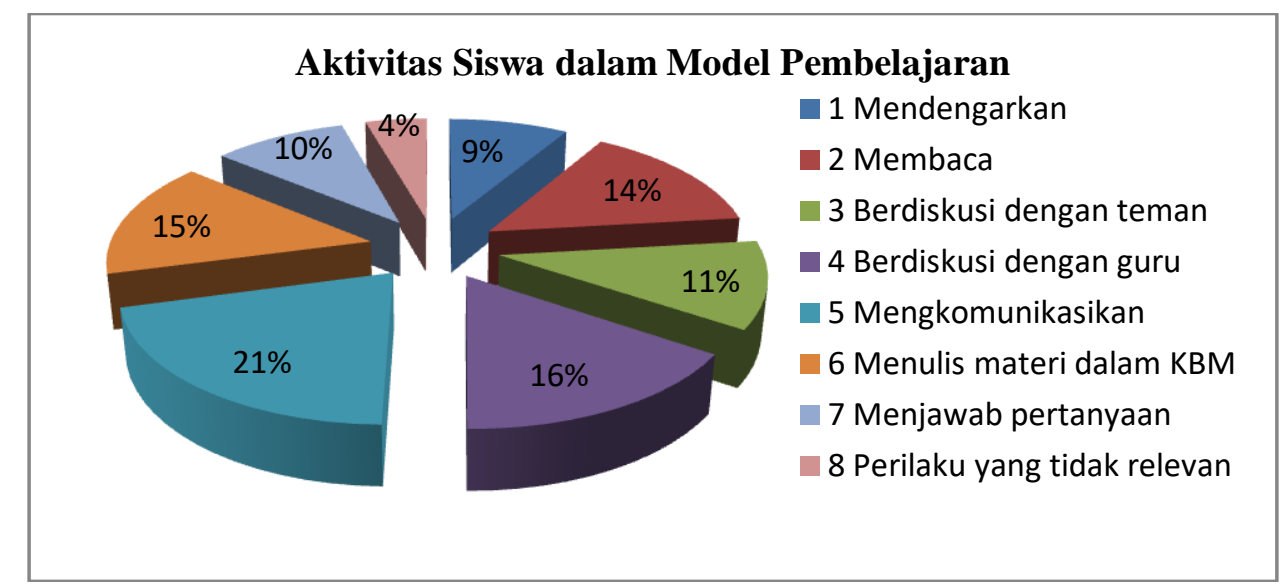

Gambar 2. Aktivitas Siswa dalam Model Pembelajaran Kooperatif Tipe Jigsaw

Berdasarkan Tabel 5 dan Gambar 2 tersebut, dapat diketahui bahwa dalam dua kali pertemuan aktivitas siswa dalam mendengarkan mencapai rata-rata $9 \%$, membaca mencapai rata-rata $14 \%$, berdiskusi antar teman mencapai $11 \%$, berdiskusi dengan guru mencapai 16\%, mengkomunikasikan mencapai 21\%, menulis yang relevan mencapai $15 \%$, menjawab pertanyaan mencapai $10 \%$, dan perilaku yang tidak relevan mencapai nilai rata-rata $4 \%$.

Dari data aktivitas siswa tersebut, akan diketahui jumlah aktivitas siswa aktif dan aktivitas siswa tidak aktif. Aktivitas siswa yang aktif yang telah dilaksanakan oleh siswa dalam pembelajaran selama 2 kali pertemuan sebesar $9 \%+14 \%+11 \%+16 \%+21 \%+15 \%+10 \%=96 \%$. Sedang aktivitas siswa yang tidak aktif yang dilakukan oleh siswa sebesar 4\%. Dari hasil tersebut total dari aktivitas siswa yang aktif mencapai $96 \%$ sedang aktivitas siswa yang tidak aktif mencapai 4\%. Hal ini menunjukkan bahwa jumlah rata-rata persentase aktivitas siswa yang aktif lebih besar dari jumlah rata-rata persentase aktivitas siswa yang tidak aktif. Dengan demikian dapat disimpulkan bahwa aktivitas siswa 
selama model pembelajaran kooperatif tipe jigsaw dengan menggunakan pendekatan active learning mencapai kategori Aktif.

3. Respon siswa.

Data respon siswa didapat dari angket. Angket dibagikan kepada siswa setelah pelaksanaan pembelajaran kooperatif tipe jigsaw dengan pendekatan active learning. Jumlah responden dalam penelitian ini adalah 24 siswa. Prosentasi jawaban respon dihitung dengan membagi jumlah jawaban responden dengan jumlah total responden dikalikan seratus persen. Hasil respon siswa dapat dilihat pada Tabel 8 .

Tabel 8. Angket Respon Siswa Terhadap Jawaban Senang/Tidak Senang

\begin{tabular}{|c|c|c|c|}
\hline \multirow[b]{2}{*}{ No } & \multirow[b]{2}{*}{ Pernyataan } & \multicolumn{2}{|c|}{ Respon siswa } \\
\hline & & Senang & $\begin{array}{r}\text { Tidak } \\
\text { senang }\end{array}$ \\
\hline 1. & Bagaimana tanggapan saudara selama mengikuti pembelajaran & 87,5 & 12,5 \\
\hline 2. & Bagaimana tanggapan saudara terhadap materi pelajaran & 83,33 & 16,67 \\
\hline 3. & $\begin{array}{l}\text { Bagaimana tanggapan saudara terhadap buku lembar kerja } \\
\text { siswa }\end{array}$ & 87,5 & 12,5 \\
\hline 4. & Bagaimana tanggapan saudara terhadap lembar materi ahli & 91,67 & 8,33 \\
\hline 5. & Bagaimana tanggapan saudara terhadap soal post test & 95,83 & 4,17 \\
\hline 6. & $\begin{array}{l}\text { Bagaimana tanggapan saudara terhadap suasana belajar } \\
\text { dikelas }\end{array}$ & 83,33 & 16,67 \\
\hline 7. & Bagaimana tanggapan saudara terhadap cara belajar & 83,33 & 16,67 \\
\hline 8. & Bagaimana tanggapan saudara terhadap cara guru mengajar & 87,5 & 12,5 \\
\hline & Rata-rata & 87,50 & 12,50 \\
\hline
\end{tabular}

Tabel 9. Angket Respon Siswa Terhadap Jawaban Baru/Tidak Baru

\begin{tabular}{ccccc}
\hline \multirow{2}{*}{ No } & \multirow{2}{*}{ Pernyataan } & \multicolumn{2}{c}{ Respon siswa } \\
\cline { 3 - 4 } & & \multicolumn{2}{c}{ Baru } & Tidak baru \\
\hline 1. & Bagaimana pendapat & saudara tentang materi pelajaran & 83,33 & 16,67 \\
\hline 2. & Bagaimana pendapat & saudara terhadap buku siswanya & 95,83 & 4,17 \\
\hline 3. & Bagaimana pendapat & saudara tentang lembar materi ahli & 91,67 & 8,33 \\
\hline 4. & Bagaimana pendapat & saudara tentang soal post test & 91,67 & 8,33 \\
\hline 5. & Bagaimana pendapat & saudara suasana belajar dikelas & 83,33 & 16,67 \\
\hline 6. & Bagaimana pendapat & saudara cara guru mengajar & 87,5 & 12,5 \\
\hline 7. & $\begin{array}{l}\text { Bagaimana pendapat } \\
\text { kooperatif dengan tipe jigsaw yang telah kalian ikuti }\end{array}$ & 83,33 & 16,67 \\
\hline \multicolumn{5}{c}{ Rata-rata } \\
\hline
\end{tabular}

Tabel 10. Angket Respon Siswa Terhadap Jawaban Setuju/Tidak Setuju

\begin{tabular}{|c|c|c|c|}
\hline \multirow[b]{2}{*}{ No } & \multirow[b]{2}{*}{ Pernyataan } & \multicolumn{2}{|c|}{ Respon siswa } \\
\hline & & Setuju & $\begin{array}{l}\text { Tidak } \\
\text { setuju }\end{array}$ \\
\hline 1. & $\begin{array}{l}\text { Bagaimana pendapat saudara jika pokok bahasan selanjutnya } \\
\text { menggunakan model pembelajaran kooperatif dengan tipe } \\
\text { jigsaw seperti yang kalian ikuti }\end{array}$ & 83,33 & 16,67 \\
\hline 2. & $\begin{array}{l}\text { Bagaimana pendapat saudara jika mata pelajaran yang lain } \\
\text { diajarkan dengan menggunakan model pembelajaran }\end{array}$ & 91,67 & 8,33 \\
\hline
\end{tabular}




\begin{tabular}{ccc}
\hline \multirow{2}{*}{ No } & Pernyataan & \multicolumn{2}{c}{ Respon siswa } \\
\cline { 2 - 3 } & Setuju & $\begin{array}{c}\text { Tidak } \\
\text { setuju }\end{array}$ \\
\hline \multicolumn{2}{c}{ kooperatif dengan tipe jigsaw seperti yang telah kalian ikuti } \\
\hline Rata-rata & $\mathbf{8 7 , 5 0}$ & $\mathbf{1 2 , 5 0}$ \\
\hline
\end{tabular}

Adapun hasil respon siswa dari tabel di atas dapat digambarkan pada diagram lingkaran dalam Gambar 3.

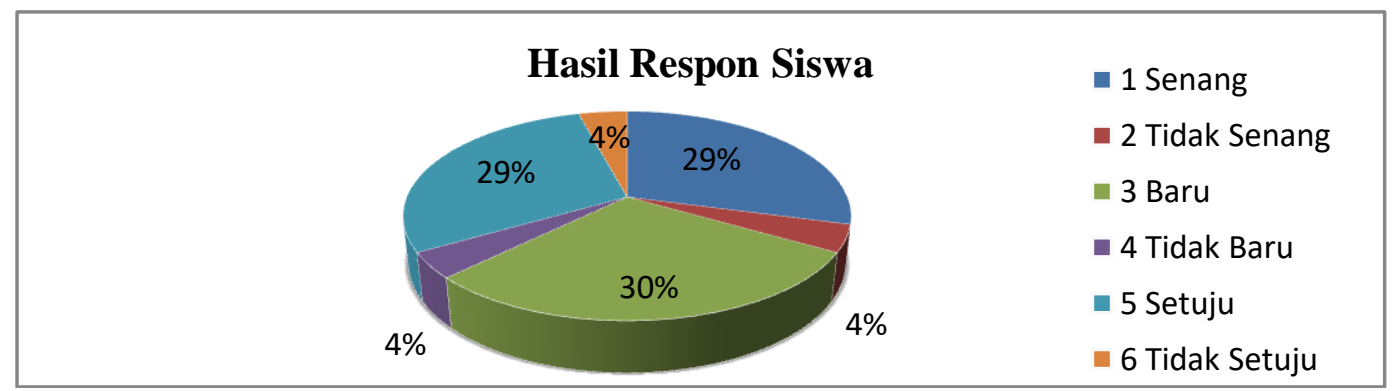

Gambar 3. Hasil Respon Siswa

Dari Tabel 8, 9, 10 dan Gambar 3 menunjukkan bahwa tanggapan siswa yang senang dalam mengikuti model pembelajaran kooperatif tipe jigsaw dengan menggunakan pendekatan active learning sebanyak $29 \%$ dengan rata-ratanya adalah 87,50 dan respon siswa yang tidak senang adalah $4 \%$ dengan rata-ratanya adalah 12,50. Respon siswa yang menyatakan baru terhadap materi dan model pembelajaran kooperatif tipe jigsaw dengan mengunakan pendekatan active learning adalah sebesar 30\% dengan rata-ratanya adalah 80,09 dan tanggapan siswa menyatakan tidak baru terhadap materi dan model pembelajaran kooperatif tipe jigsaw dengan mengunakan pendekatan active learning adalah sebesar adalah 4\% dengan rata-ratanya adalah 11,91. Respon Siswa yang setuju dengan model pembelajaran kooperatif tipe jigsaw dengan menggunakan pendekatan active learning adalah sebanyak 29\% dengan rata-ratanya adalah 87,50 dan tanggapan siswa yang tidak setuju adalah sebanyak $4 \%$ dengan rata-ratanya adalah 12,50.

Dari penjelasan tersebut, dapat diambil kesimpulan bahwa siswa senang dalam model pembelajaran kooperatif tipe jigsaw memperoleh nila rata-rata 87,50 atau persentasenya $29 \%$, siswa baru mengenal materi dan model pembelajaran kooperatif tipe jigsaw nilai rata-ratanya 88,09 atau persentasenya 30\%, dan siswa setuju dengan model pembelajaran kooperatif tipe jigsaw memperoleh nilai ratarata 87,50 atau persentasenya $29 \%$. Karena siswa yang menyatakan 
senang/baru/setuju terhadap pelaksanaan model pembelajaran kooperatif tipe jigsaw dengan menggunakan pendekatan active learning $\geq 80 \%$. Maka model pembelajaran kooperatif tipe jigsaw dengan menggunakan pendekatan active learning adalah direspon baik dan positif oleh siswa.

4. Hasil belajar kognitif siswa.

Tes hasil belajar dilaksanakan setelah mengikuti model pembelajaran kooperatif tipe jigsaw dengan menggunakan pendekatan active learning. Tes hasil belajar ini digunakan untuk menentukan ketuntasan belajar siswa. Siswa dapat dikatakan tuntas dalam belajar apabila memperoleh nilai minimal 75 atau memperoleh nilai $\geq 75 \%$, data hasil belajar siswa dapat dilihat pada Tabel 11 .

Tabel 11. Hasil Belajar Kognitif Siswa

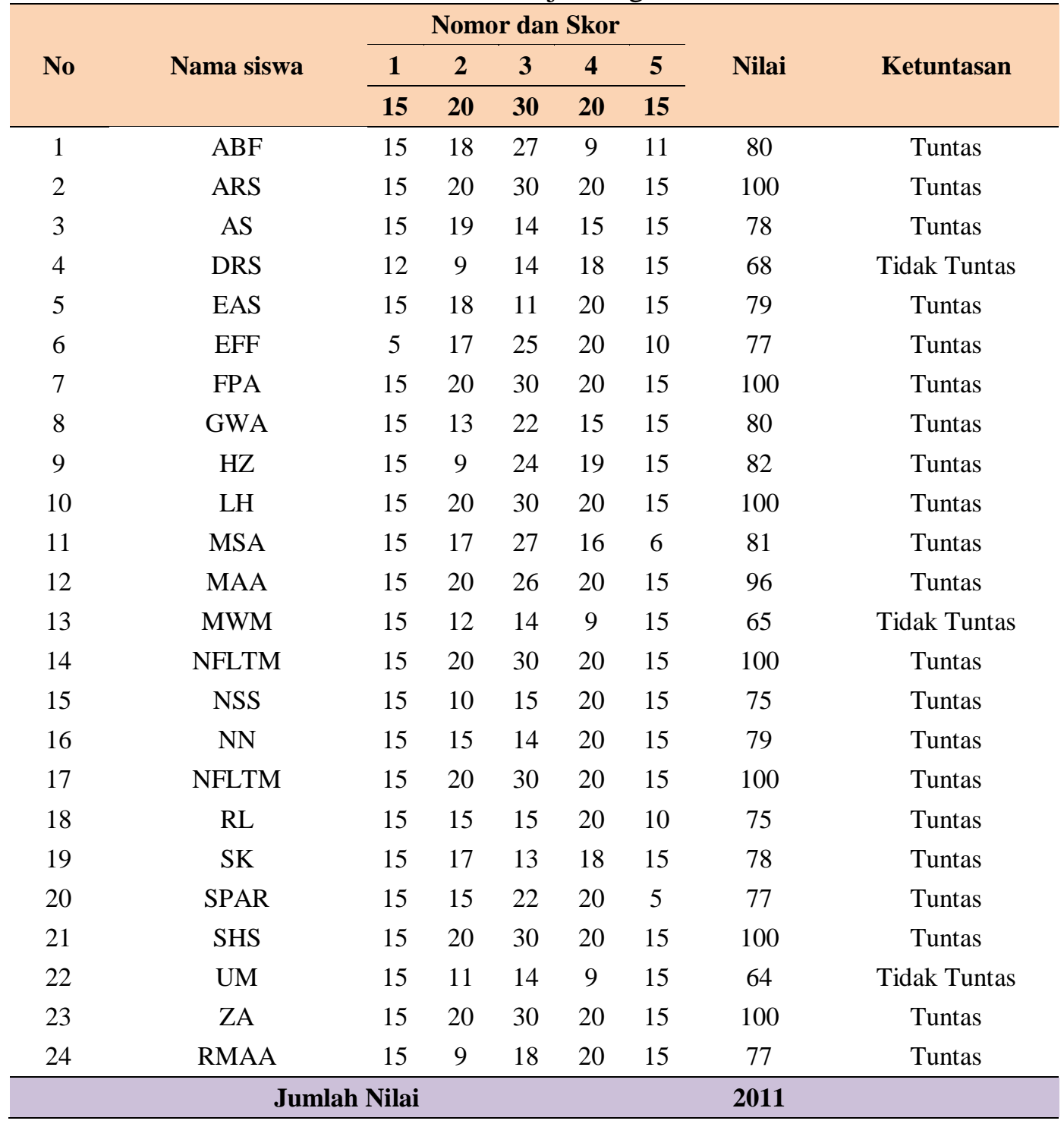




\begin{tabular}{cc}
\hline Ketuntasan $(\%)$ & $\mathbf{8 7 , 5 0}$ \\
\hline Rata-Rata & $\mathbf{8 3 , 7 9}$ \\
\hline
\end{tabular}

Adapun hasil ketuntasan siswa dalam model pembelajaran kooperatif tipe jigsaw dengan menggunakan pendekatan active learning, dapat digambarkan pada diagram lingkaran pada Gambar 4.

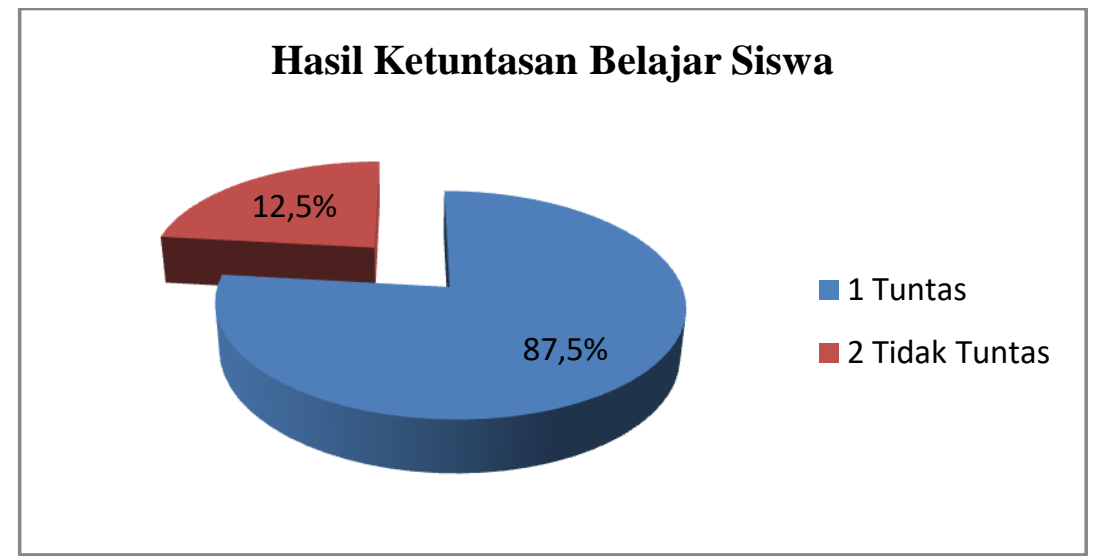

Gambar 4. Hasil Ketuntasan Belajar Siswa

Berdasarkan Tabel 11 dan Gambar 4 tersebut, dapat disimpulkan bahwa siswa dikategorikan tuntas dalam belajar dengan jumlah 21 siswa dengan persentase $87,5 \%$ sedangkan kategori siswa yang tidak tuntas sebanyak 3 dengan persentase $12,5 \%$. Sedangkan ketuntasan setiap siswa diambil dari KKM mata pelajaran yang dibuat oleh guru matematika minimal 75 .

5. Ketuntasan pembelajaran pada butir soal

Ketuntasan pembelajaran pada butir soal dilaksanakan setelah mengikuti model pembelajaran kooperatif tipe jigsaw dengan menggunakan pendekatan active learning dengan skor 1 apabila siswa menjawab soal dengan benar dan skor 0 apabila siswa menjawab soal salah, Sedangkan siswa dikatakan tuntas apabila siswa menjawab soal dengan benar $\geq 4$ dan siswa tidak tuntas apabila menjawab soal dengan benar $\leq 3$. Data ketuntasan pembelajaran pada butir soal dapat dilihat pada Tabel 12.

Tabel 12. Ketuntasan Pembelajaran pada Butir Soal

\begin{tabular}{cccccccccc} 
& & \multicolumn{9}{c}{ Nomor butir soal } & & Jumlah & Tercapaian \\
\cline { 3 - 6 } No & Nama siswa & $\mathbf{1}$ & $\mathbf{2}$ & $\mathbf{3}$ & $\mathbf{4}$ & $\mathbf{5}$ & jawaban benar & $\begin{array}{c}\text { Tuntas/tidak } \\
\text { tuntas }\end{array}$ \\
\cline { 2 - 6 } & $\mathbf{1 5}$ & $\mathbf{2 0}$ & $\mathbf{3 0}$ & $\mathbf{2 0}$ & $\mathbf{1 5}$ & & Tuntas
\end{tabular}




\begin{tabular}{|c|c|c|c|c|c|c|c|c|c|}
\hline \multirow{3}{*}{ No } & \multirow{3}{*}{ Nama siswa } & \multicolumn{5}{|c|}{ Nomor butir soal } & \multirow{3}{*}{$\begin{array}{c}\text { Jumlah } \\
\text { jawaban benar }\end{array}$} & \multirow{3}{*}{$\begin{array}{c}\text { Tercapaian } \\
(\%)\end{array}$} & \multirow{3}{*}{$\begin{array}{c}\text { Tuntas/tidak } \\
\text { tuntas }\end{array}$} \\
\hline & & \multirow{2}{*}{$\begin{array}{c}1 \\
15\end{array}$} & \multirow{2}{*}{$\begin{array}{c}2 \\
20\end{array}$} & \multirow{2}{*}{$\begin{array}{c}3 \\
30 \\
\end{array}$} & \multirow{2}{*}{$\begin{array}{c}4 \\
20 \\
\end{array}$} & \multirow{2}{*}{$\begin{array}{l}5 \\
15 \\
\end{array}$} & & & \\
\hline & & & & & & & & & \\
\hline 2 & ARS & 1 & 1 & 1 & 1 & 1 & 5 & 100 & Tuntas \\
\hline 3 & AS & 1 & 1 & 0 & 1 & 1 & 4 & 80 & Tuntas \\
\hline 4 & DRS & 1 & 0 & 0 & 1 & 1 & 3 & 60 & Tidak Tuntas \\
\hline 5 & EAS & 1 & 1 & 0 & 1 & 1 & 4 & 80 & Tuntas \\
\hline 6 & $\mathrm{EFF}$ & 0 & 1 & 1 & 1 & 1 & 4 & 80 & Tuntas \\
\hline 7 & FPA & 1 & 1 & 1 & 1 & 1 & 5 & 100 & Tuntas \\
\hline 8 & GWA & 1 & 1 & 1 & 1 & 1 & 5 & 100 & Tuntas \\
\hline 9 & $\mathrm{HZ}$ & 1 & 0 & 1 & 1 & 1 & 4 & 80 & Tuntas \\
\hline 10 & LH & 1 & 1 & 1 & 1 & 1 & 5 & 100 & Tuntas \\
\hline 11 & MSA & 1 & 1 & 1 & 1 & 0 & 4 & 80 & Tuntas \\
\hline 12 & MAA & 1 & 1 & 1 & 1 & 1 & 5 & 100 & Tuntas \\
\hline 13 & MWM & 1 & 1 & 0 & 0 & 1 & 3 & 60 & Tidak Tuntas \\
\hline 14 & NFLTM & 1 & 1 & 1 & 1 & 1 & 5 & 100 & Tuntas \\
\hline 15 & NSS & 1 & 1 & 1 & 1 & 1 & 5 & 100 & Tuntas \\
\hline 16 & $\mathrm{NN}$ & 1 & 1 & 0 & 1 & 1 & 4 & 80 & Tuntas \\
\hline 17 & NFLTM & 1 & 1 & 1 & 1 & 1 & 5 & 100 & Tuntas \\
\hline 18 & $\mathrm{RL}$ & 1 & 1 & 1 & 1 & 1 & 5 & 100 & Tuntas \\
\hline 19 & SK & 1 & 1 & 0 & 1 & 1 & 4 & 80 & Tuntas \\
\hline 20 & SPAR & 1 & 1 & 1 & 1 & 0 & 4 & 80 & Tuntas \\
\hline 21 & SHS & 1 & 1 & 1 & 1 & 1 & 5 & 100 & Tuntas \\
\hline 22 & $\mathrm{UM}$ & 1 & 1 & 0 & 0 & 1 & 3 & 60 & Tidak Tuntas \\
\hline 23 & $\mathrm{ZA}$ & 1 & 1 & 1 & 1 & 1 & 5 & 100 & Tuntas \\
\hline 24 & RMAA & 1 & 0 & 1 & 1 & 1 & 4 & 80 & Tuntas \\
\hline $\begin{array}{r}\text { Ju } \\
\text { men }\end{array}$ & $\begin{array}{l}\text { Imlah yang } \\
\text { jawab benar }\end{array}$ & 23 & 21 & 17 & 21 & 22 & & & \\
\hline Ket & $\begin{array}{l}\text { untasan butir } \\
\text { soal }(\%)\end{array}$ & 96 & 88 & 71 & 88 & 92 & & & \\
\hline
\end{tabular}

Adapun hasil ketuntasan pembelajaran pada butir soal dalam model pembelajaran kooperatif tipe jigsaw dengan menggunakan pendekatan active learning, dapat digambarkan pada diagram lingkaran pada Gambar 5.

Berdasarkan Tabel 12 dan Gambar 5 ketuntasan pembelajaran pada butir soal untuk butir soal nomor 1 mencapai ketuntasan 96\%, butir soal nomor 2 mencapai ketuntasan $88 \%$, butir soal nomor 3 mencapai ketuntasan $71 \%$, butir soal nomor 4 mencapai ketuntasan $88 \%$ dan butir soal nomor 5 mencapai ketuntasan 92\%. Jika keruntasan tersebut dicermati, Ketuntasan ini disebabkan karena pendekatan pembelajaran active learning dan model pembelajaran kooperatif tipe jigsaw yang 
digunakan adalah menarik perhatian siswa, sehingga siswa dapat mengikuti pelajaran dengan sungguh-sungguh. Hal ini dapat dilihat pada saat proses pembelajaran dengan model pembelajaran kooperatif tipe jigsaw dengan menggunakan pendekatan active learning. Siswa terlibat secara aktif dan menguasai pelajaran dengan baik dan dapat mengerjakan soal yang diberikan dengan mudah. Sejalan dengan penelitian yang dilakukan oleh Thomas (2014) menghasilkan penelitian bahwa pelaksanaan pembelajaran kooperatif tipe jigsaw dan hasil tes yang dilaksanakan merupakan salah satu upaya yang tepat untuk memaksimalkan hasil belajar siswa terutama pada kompetensi dasar standar nasional pendidikan. Hal ini mendukung perubahan paradigma pembelajaran yang beralih dari teacher oriented ke learner oriented dengan penggunaan metode belajar bervariatif yang mampu menggali dan mengembangkan potensi siswa dengan mengedepankan proses belajar mandiri melalui aktivitas belajar seperti pendekatan kooperatif tipe jigsaw.

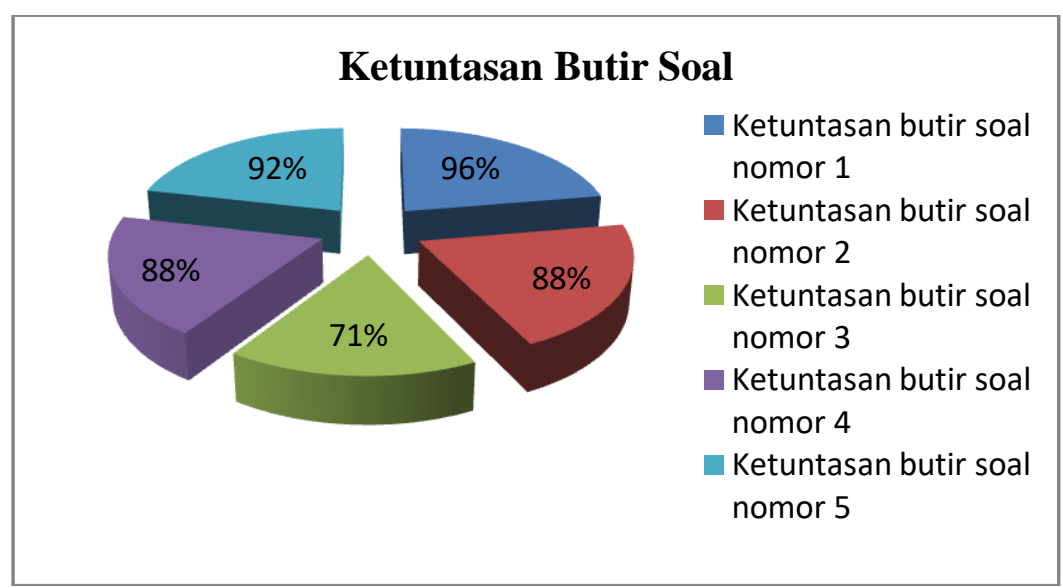

Gambar 5. Ketuntasan Butir Soal

\section{SIMPULAN}

Berdasarkan hasil penelitian dan pembahasan yang telah dikemukakan diatas, maka dapat disimpulkan: 1) Kemampuan guru dalam mengelola model pembelajaran kooperatif tipe jigsaw dengan menggunakan pendekatan active learning dengan mencapai skor 3,19 dan termasuk kategori sangat baik; 2) Siswa aktif ketika pembelajaran berlangsung. Hasil pengamatan aktivitas siswa diperoleh aktivitas siswa aktif mencapai 96\%, sedang aktivitas siswa tidak aktif mencapai 4\%. Artinya selama pembelajaran kooperatif tipe jigsaw dengan menggunakan pendekatan active learning, siswa secara aktif mengkontruksi pengetahuanya dari dirinya sendiri. Dari hal tersebut maka aktivitas siswa 
dikatakan aktif karena prosentase aktivitas siswa yang aktif lebih tinggi dari pada aktivitas siswa yang tidak aktif; 3) Respon siswa terhadap pembelajaran sangat positif. Dari hasil angket respon siswa diperoleh $87,55 \%$ siswa menjawab senang dan tidak senang diperoleh $12,55 \%$, siswa menjawab baru $88,09 \%$, dan $11,9 \%$ siswa menjawab tidak baru, siswa menjawab setuju $88,50 \%$ dan tidak setuju 12,50\%. Sehingga dari hasil tersebut dapat disimpulkan bahwa model pembelajaran kooperatif tipe jigsaw dengan menggunakan pendekatan active learning mendapat respon positif dari siswa, artinya pembelajaran ini dapat diterima oleh siswa dan dapat membantu siswa memahami pelajaran; 4) Hasil belajar siswa dengan model pembelajaran kooperatif tipe jigsaw dengan menggunakan pendekatan active learning dapat dikatakan efektif. Hal ini dapat dilihat dari nilai hasil persentase ketuntasan belajar siswa secara individu $77 \%$ siswa tuntas dan $23 \%$ siswa tidak tuntas. Sedangkan secara klasikal ketuntasan belajar siswa mencapai $76,81 \%$ karena terdapat 3 siswa yang mendapat nilai $<75$. Hal ini disebabkan karena siswa dituntut untuk dapat berperan aktif dalam pembelajaran.

\section{DAFTAR PUSTAKA}

Hardini \& Puspitasari (2012). Strategi Pembelajaran Terpadu (Teori, Konsep, \& Implementasi). Yogyakarta: Familia.

In'am (2012). Model Pembelajaran Matematika Berbasis Metakognitif. Malang: Selaras.

Isjoni (2007). Cooperative Learning Efektifitas Pembelajaran Kelompok. Bandung: Alfabeta.

Lie (2002). Cooperative Learning. Jakarta: Gramedia Widiasarana Indonesia.

Lince (2001). Efisiensi Pengajaran. Jakarta: Balai Pustaka.

Masykur \& Fathani (2007). Mathematical Intelligence Yogyakarta: Ar-Ruzz media.

Nur, M., \& Wikandari, R. P. (1999). Pengajaran Berpusat Kepada Siswa Dan Pendekatan Konstruktivis Dalam Pengajaran. Surabaya: UNESA.

Rusiyanti (2011). Pengembangan Perangkat Pembelajaran Matematika berbasis Kontruktivisme untuk melatih Kemampuan Berpikir Kritis Siswa SMA kelas X. Jurnal Pendidikan Matematika, 5(2),185-205.

Thomas, P. (2014). E-learning dengan pendekatan kooperatif tipe jigsaw untuk meningkatkan aktivitas dan hasil belajar mahasiswa. Jurnal pendidikan ekonomi dinamika pendidikan. JPE DP, IX(1), 21-40. 
Safrina, dkk. (2014). Peningkatan Kemampuan Pemecahan Masalah Geometri melalui Pembelajaran Kooperatif Berbasis Teori Van Hiele. Jurnal Didaktik Matematika, 1(1). 9-20.

Simon S., Erduran, S. \& Osborne J. (2006). Learning to teach argumentation: research and development in the science classroom. International Journal of Science Education. 28(2-3). 235-260.

Slavin, R. E. (2015). Cooperative Learning: Teori, Riset dan Praktik. Bandung: Nusa Media

Sriyanto, H. J. (2007). Easy Math. Yogyakarta: Pustaka Widyatama.

Sugiyono (2014). Metode Penelitian Pendidikan. Bandung : Alfabeta.

Sukiyanto, S. (2018). Pengembangan rencana pembelajaran matematika dengan model kooperatif tipe STAD dan teori Vygotsky. de Fermat: Jurnal Pendidikan Matematika. 1(2). 31-41. 